\title{
Polish uni academics and
} \section{government}

Poland's new Higher Education Act, the subject of eighteen months' negotatiations and confrontations - including the threat, last September, of a nationwide university strike - became law last week. The act makes several formal concessions to academics' aspirations for self-governance, but at the same time reserves to the Minister of Science, Higher Education and Technology the last word on a number of key issues.

Students, likewise, get a compromise deal - they have won the right to express their views and form associations but will not be allowed to stage protest actions since, it was explained during the parliamentary debate on the bill, "they do not belong to the community of employees".

The new act gives the minister power to monitor the resolutions adopted by university self-governance bodies and decisions taken by university rectors, and to reverse them should he decide they are inconsistent with the law. Rectors of universities and other higher colleges will be elected by the bodies themselves, the electors being either the university senate or a special collegium. The minister, however, retains the right of veto over elections - providing that he registers his objection within fourteen days.

On these and other questions, there is to be a Main Council for Science and Higher Education to hold the ring, and whose role has been negotiated between the ministry and the Social Drafting Commission - a body representing academics, students, scholars, the trade unions and the Church, which at one stage proposed its own draft bill. The council is in effect a revival under a new name of a moribund body meant to act as an intermediary between academics and the ministry.

The new act gives the council the status of the supreme elective organ of the academic community, with powers to decide on the direction of research and the organization of studies.

The Social Drafting Commission, however, had sought even wider powers for the Main Council. In the event, as Professor Zbigniew Resich, the head of the commission, said last week, "a whole series of important powers" had passed into the minister's hands.

Another major issue has been the dismissal of academic staff. The Social Drafting Commission, said Professor Resich, had considered that a lecturer's contract could be terminated only after disciplinary proceedings. In its final form,

\section{versity compromise}

the act now contains other possibilities, including the dismissal of junior members of staff (up to and including assistant professors) after two "negative assessment reports". It is not yet clear who would make these assessments, although it seems that the rights of the professorial body will be safeguarded, since any such dismissal must have the consent of the Council of State. But there is some evidence that "assessments"' by bodies outside the university are envisaged, another limitation of "self-governance".

Similarly, although the act formally acknowledges the principles of academic freedom, including differences of "world outlook", implementation of these principles, in undergraduate teaching at least, will be constrained by what Professor Resich called "strong emphasis" in the act on the "need to teach and bring up youth in accordance with socialist principles"'.

These other features of the act are intended to emphasis the state character of higher education in Poland, according to the minister, Dr Benon Miskiewicz. He himself was "following with anxiety" the participation of students and academics in illegal demonstrations, and stressed the role of the universities in ideological and political education.

His concern was timely; in Warsaw alone, six higher education establishments were represented in the arrests following last week's demonstratrations. Students were equally prominent in the demonstrations in Szczecin Gliwice and in the Gdansk-Sopot-Gdynia conurbation.

These demonstrations, which took place in spite of the threat of heavy summary sentences under the emergency regulations, clearly reflect the students' bitterness at the banning of the Independent Students' Association (NZS) and the loss of many of the privileges granted in 1981. The new Higher Education Act is hardly likely to assuage their resentment.

\section{Contraction for London university}

A proposal by a Joint Planning Committee that the teaching of science in the University of London should be concentrated on five sites was accepted by the senate of the university at its meeting on 29 April. No timetable for the concentration of the university is provided.

This is the university's response to the prospect of an income that will have shrunk by about 15 per cent between 1981-82 and 1983-84, and to earlier reports by the six committees set up to recommend rationalization of teaching in six subject areas. Most committees recommended that teaching should be concentrated at fewer sites.

The planning committee, however, says that these reports reflect "inadequate information" and make comments "that cannot be justified in the light of the facts"'. In practice, the committee responsible for biological sciences, under its independent chairman Sir James Beament, began last October by assuming that student numbers need not fall as sharply as had been decreed. The committee's second attempt under a second chairman follows the general pattern of recommending concentration on five sites.

The joint planning committee itself is hoping for some relief from the rigours prescribed by the University Grants Committee (UGC). When added together, the recommendations of the six subject committees on student numbers for the year 1983-84 imply that student numbers would then be 1,000 greater than the UGC target. The planning report says that the grants committee has been asked to agree to a larger target number or, alternatively, that the university should have an extra year in which to make the adjustment.

On research support, the planning committee applauds the study now being carried out by the court of the university of the suggestion that financial allocations to the separate London colleges should deal separately with teaching and research. This proposal, put forward last November by Sir James Lighthill, Principal of University College, is regarded as a way of helping to avoid the consequences of the erosion of the dual-support system in the past few years, and also of making explicit the reasons why some colleges in London appear to be dealt with more generously than others. But it seems unlikely that anything will come of this before the court of the university shares out the funds available for the next academic year.

The planning committee's recommendations are that undergraduate science teaching in the university should be concentrated at five sites, where all science subjects would be taught. There are similar proposals for concentration in the arts and the humanities.

The next step in the saga of the University of London will come on 19 May, when the court of the university is to meet for a preliminary assessment of how to divide next year's grant. The exact amount will not be known until the university has heard from UGC at the end of May.

Opinion among senior members of the university is divided about the extent to which the new policy will influence next year's distribution of funds within the university. Some think that the court will be bound to distribute what money there is as the planning committee says it should. Others hold that the university will have to respect the autonomy of its colleges. 